\title{
CHANGE OF AMERICAN MIGRATION POLICIES AND THE CONSEQUENCE OF INFLATION OF ASSIMILATION AMONG ARAB AMERICANS
}

\author{
Mohammed Yassin Mohd Aba Sha'ar \\ Aligarh Muslim University \\ amohammedyassin@yahoo.com \\ Nur Lailatur Rofiah \\ Universitas Gresik \\ lila.doank@gmail.com
}

\begin{abstract}
United States has been well known as the country of immigrants since 1492. Over the years, people used to migrate to the United States from all over the world in order to share the vantages of the 'American Dream'. Arabs started their systematic migration to the United States in the 1870s. Initially they perceive themselves as immigrants whose aim is to earn economic amelioration. This article traces the history of Arab migration to the United States and exposes the multifarious push and pull-factors behind the migration of each wave. Constantly, the United States used to impose deliberate migration laws that aim to either to restrict or recruit immigrants from particular races and nationalities. Thereby, this paper reviews different legislations and policies that have been executed by American authorities in order to restrict or ban the Arab immigrants from migrating to the United States. Consequentially, such legislations contributed in the isolation of the Arab immigrants from the other worlds.
\end{abstract}

Keywords: Arab Americans, assimilation, inflation,

\begin{abstract}
Abstrak
Amerika adalah dikenal sebagai negara imigran sejak tahun 1492. Bertahun-tahun orangorang bermigrasi ke Amerika dari seluruh dunia untuk menikmati sebuah 'Mimpi Amerika' . Orang Arab memulai migrasi yang sistematis ke Amerika tahun 1870-an. Awalnya mereka memandang diri sebagai pendatang yang bertujuan untuk mencapai perbaikan ekonomi. Makalah ini menelusuri sejarah migrasi orang Arab ke Amerika dan menjelaskan faktor tarik-menarik di balik gelombang migrasi. Seringkali Amerika memaksakan undangundang migrasi yang bertujuan untuk membatasi atau merekrut imigran dari ras dan kebangsaan tertentu. Oleh karena itu, makalah ini mengulas peraturan perundangundangan dan kebijakan yang berbeda yang dijalankan oleh pemerintah Amerika untuk membatasi imigran Arab agar tidak bermigrasi ke Amerika. Konsekuens undang-undang tersebut berkontribusi dalam mengisolasi imigran Arab dari negara lainnya.
\end{abstract}

Kata Kunci: $\quad$ Arab Amerika, asimilasi, inflasi 
INJECT: Interdisciplinary Journal of Communication, Vol.2, No.2, Des. 2017: h. 235-246

\section{Introduction}

The Arab started migrating to America since the last decades of $19^{\text {th }}$ century for various pull and push factors. The influx of their migration has been facing many ebbs and flows but still is going on to the present day. Meantime, the United States used to modify and change its policies of migration either to curtail the migration flow or for other purposes. There are particular acts which were legislated and resulted in either the intensification of assimilation among Arab Americans or the accretion of their adherence to their cultural heritage and identity. There are many other challenges and pressing issues that used to urge them to assimilate into the American culture and society, dissociating from and shedding off the old loyalties. Thereby, this paper demonstrates how the assimilation process of Arab Americans is similar to the economic inflation-the intensification of assimilation among Arab American results in the dwindling of their cultural heritage and language. Moreover, not all the Arab Americans assimilate completely into the American mainstream culture but there are some Arab Americans who were "Americanized to the point of extinction".

\section{Brief Chronicle of Arab Migration to The New World}

At the outset, the word Arab is a geographical label which refers to a person who belongs to the Arab world. Racially Arabs "are a group of people who trace their origins to Arab ancestry inhabiting North Africa and Southwest of Asia. They are Semites whose culture is not dissimilar from other Semite cultures in the Middle East. Briefly, the period of Arab migration has been divided into three waves and inter-war period.

\section{The Waves of Arab Migration to America}

The first wave starts from 1870s to 1918. Arab immigrants in this wave came from 'Greater Syria' which today includes Syria, Lebanon, 
Palestine and Jordan. Their migration was caused by several factors such as the opening of the Suez Canal in 1869 and the change on trade route to the Egypt, the collapse of silk trade after the influx of the Chinese and Japanese silk into the European markets with cheaper and better quality, the oppression and biasness of the Ottoman authorities, the increase of taxation, conscription, the enticement of the American missionaries who constantly used to talk about the privileges and rights of living in American, the lack of freedom, the improvement of transportation and the increase of population without any increase in the agricultural and industrial productions (Ameri and Arida, 2012; Kayyali, 2006). They engaged in peddling and it gave them a chance to know many American values, traditions and life style (Naff, 1994). Beside it was a period in which nativists and institutionalized movements were pressing on the immigrants to adopt the American traditions, customs and values and to assimilate into the American mainstream culture and society (NassarMcMillan et al., 2013). In addition, their assimilation process was heightened after they were acknowledge as white race 1924 -'eligible for naturalization and citizenship'. After World War I is over, then came the 'Inter War Period'. It started from 1918 to 1948. In fact the influx of Arab immigrants in this period was interrupted during the time of warfare but there are some of them who managed to migrate in such conditions. The flow of Arab immigrants after World War I started to revive a little but it received a serious hit by the imposition of Johnson Reed Act in 1924. In this period assimilation process of Arab American increased dramatically. However migration continues in a process dubbed as 'chain migration' in which wives, children and other members were allowed to join their family members in US. Thereafter, 'The Second Wave' started from 1948 to 1965. The Arab immigrants were diverse as they came from different countries, adhering to various faiths and cultures. Unlike immigrants of the first waves; they are highly educated, politicized and professionals. They migrated due to the social economic and political 
instability; they desire to search for better economic opportunities. The new Muslim immigrants were alienated in the American society by the Americans and by their predecessors who already assimilated completely to the American white middle class strata (Nassar-McMillan et al., 2013). They were educated and as a consequence they easily adopted the American culture and life style. Then 'The Third Wave' starts from 1965 till today. The number immigrants increased dramatically after loosening of migration policies in 1965-Hart Celler Act. They were pushed due to regional conflicts and civil wars that consequentially caused social and political instability in many Arab countries. Others migrated due to the oppression, lack of freedom, religious conflicts and the implementation on nationalization policy in some countries. Unlike the previous waves; they were more desirous to participate in the American politics in order to affect the American policies in the Arab world (Nassar-McMillan et al., 2013). Thereby, the term 'Arab Americans' refers to those who trace their roots to Arab ancestry and currently living in the United States. In January 29, 2017 The American New President Donald Trump signed an executive order to ban immigrants from seven Muslim majority countries.

\section{Remarkable Acts That Changed Migration Policies to Arab}

According to Ameri and Arida (2012) "the anti-immigrants rhetoric and political pressure was exerted by the nativists and the early European immigrants who migrated to the United States as they were more established and influential in the American society and government"(10). They instructed the American government to pass different legislations and acts between 1917 and 1924 that consequentially led to the restriction of migration from most parts of the world. But since the last decades of $20^{\text {th }}$ century and the beginning of $21^{\text {st }}$ century such pressure started to be exerted by the extremist wing of the Republican Party and the Jewish and/or pro-Israeli organizations that have been succeeding economically and politically in the American society. 
The First act that targeted the Arab Americans is called 'National Origin Act or Johnson Reed Act which reduced the annual number the admitted immigrants to $2 \%$ of particular origins and races from the number of immigrants of that race or origin according to the census of 1890 . It seriously restricted the migration flow from Africa, Eastern Asia and Southern Europe including the Arab immigrants. But the international pressure of organizations like the UN and the domestic pressure of civil rights activists led by Dr. Martin Luther King in the 1960s resulted in the abolition of the migration restriction that based on ethnicity, race or national origin. Hart Celler Act in 1965 ended up all the restrictions and opened the doors for all the races and nationalities from all over the world. In October 23, 2001 the American president G.W Bush Signed USA Patriot Act which provides appropriate tools required to intercept and obstruct terrorism. This legislation was passed by the American congress in order to strengthen security control after the terrorists' attack of September 11. This act gave the (FBI) the right to detain, deport, eavesdrop on the phones and e-mails of particular persons and raid houses and places of work without court order. It mostly targeted the Arab and Muslim Americans but it did not last long; it expired on June 1, 2015 (Kelly, 2015). In Jan 29, 2017 the American president Trump signed executive order to "suspended all the US refugee admissions system for 120 days and to ban the entry of Muslims from seven majority-Muslim countries - Iran, Iraq, Libya, Somalia, Sudan, Syria and Yemen - for 90 days" (Yuhas and Sidahmed, 2017).

\section{Reasons for These Legislative Changes}

Over the years the Americans policy makers and even the public believe in and deal with what Michael Hunt says the 'hierarchy of race'. Americans belief in the social Darwinism and the white supremacy of Saxons created a mental map which divides the people into civilized racesAmerica and Western Europe and backward, primitive or underdeveloped 
races like Latinos, Africans, Asians and American Indians. The Middle East and the Arab world used to be classified with the 'Third World Countries' placing them in the bottom of the racial order.

In the early $20^{\text {th }}$ century Americans was afraid of the dissemination of communists' ideology in the American society, so they legislated some acts that curtailed the migration flow from Eastern and Southern Europe. But since the 1980s and after the collapse of the Soviet Union, the Americans began considering Arabs and Muslims as the arch enemy whilst not all the Arabs are Muslims and vice versa. They started disseminating stereotypes through multifarious mechanisms about Arabs and Muslims in all the western countries. In the US such stereotyping about Arabs and Muslims led to the phobia, hate, discrimination and stigmatization among Americans and further the legislating many laws that restrict their migration and treating those who already were there as 'eternal other and descendants of the distant enemy". In the $21^{\text {st }}$ century they realized these attempts are futile and Islam is continuing to thrive in the American and Europe societies. They became obsessed with what is called Islamization or Muhammadization of America. As a result Donald Trump signed an executive order to ban immigrants from seven majority Muslim countries. He openly used to normalize Islamophobia and anti-Arab sentiments in most of his speeches. Thereby, the alleged aim of his latest ban of Muslim immigrants is to "protect the Americans from terrorist's attacks committed by foreign nationals (Goitein, 2017). Others find the aim of this ban is "not to exclude Muslims from the country; it is to exclude sharia supremacists (McCarthy, 2017).

\section{Inflation of Assimilation Among Arab Americans}

Arab immigrants began to acquire and adopt some American values, traditions and other cultural aspects through their first-hand contact with the American society. The change of American migration 
policies results in co-occurring and accretion of assimilation among Arab Americans. It is almost similar to the 'economic inflation' that refers to the increase of prices of goods and services which results in the decrease of the purchasing power as it is linked to the exchange rate. More tellingly, the change of the American migration policies that concern the Arab Americans in US results in the decrease of the commitment of the Arab Americans to the old cultural heritage and language as they are unfavorable to the American mainstream culture and society. As a consequence the Arab Americans increase their assimilation and shed the old loyalties in order to fit in the American society.

Earlier the contact of Arab immigrants with the Americans through their daily lives and peddling profession initiated virtually the assimilation process. They began adopting many American values, traditions and comportments. But in 1924 the American congress passed 'Johnson Reed Act' which isolated the Arab immigrants almost completely from their homelands as it restricted the entrance of new immigrants, urging those who already in America to stay permanently. Thereby, they commenced conceding their cultural heritage and language. Their assimilation process increased dramatically and strengthened by the long isolation from the Arab world, the inability to return to their homeland and the coming of the second generation. "The second generation (American born generation) is considered as the most assimilated of all generations of Arab immigrants to the United States" (Nassar-McMillan et al., 2013). The Americanization process in this period began as the Arab immigrants accepted the American culture. Besides, "the Arab immigrants were desirous to become full Americans professionally, socially and politically as they Anglicized their names, appearance and even the religious beliefs". Their success in the professional and commercial domains instigated them to ignore teaching their children Arabic and culture. Thereby their children became unable to speak Arabic and moved instantly from the ethnic churches into the American churches (Nassar-McMillan et al., 2013). 
INJECT: Interdisciplinary Journal of Communication, Vol.2, No.2, Des. 2017: h. 235-246

"They started shedding their ethnic differences and placing it with American content and outlook" (Nassar-McMillan et al., 2013, 20). Michael Suleiman (1999) asserts "in this period they became indistinguishable from the host society (9).

But after 1967 war with Israel and the exposition of the American pro-Israeli policies, assimilation process of Arab American was destabilized greatly. However it cannot be said assimilation process of Arab Americans ceased completely, instead there have been many them who have been assimilating or assimilated completely especially those who reject the Arab ancestry and/or identity. In the one hand, some of the new comers and the American born generations attempted to cope with the two cultures but they encountered many challenges like discrimination, violence and stereotypes whilst some eschew such challenges and opted to heighten their assimilation. Besides, there are some others who reject the Arab culture and identity, dissociating themselves from it and adopting the host culture. Because they want to be fully Americans and therefore they shed all the loyalties of the original culture.

After 9/11 attacks and the legislation of US Patriot Act in 2001 the Arab Americans started to be treated like the German after WWI, the Japanese after WWII and the Jews during the Cold War. They encountered suspicion, discrimination, violence, stigmatization and dehumanization. Consequentially, the process of being and/or becoming American has been protracted and become painful. The backlash against Arab Americans after 9/11 forced most of the Arab Americans to revive and keep adhering to their ethnic identity and culture. Meanwhile there are some others who become silent 'invisible' or reacted with denial to their origin and Arab identity. They decided to intensify their invisibility and assimilation process and become fully Americans. More tellingly, "Christian Arab Americans distanced themselves from being called Arab Americans (Kayyali, 2006:107) in order to demonstrate that they are not 
terrorists or terrorist sympathizers (Jamal and Naber, 2008). Therein, they decided to increase their assimilation and continue their successful life without their ethnic identification or original culture which became unwelcomed in the American society. Besides, their aim is to evade discrimination, violence, hate, stigmatization, rejection for their origin and/or race.

In 2017 Donald Trump signed an executive order to ban immigrants from seven majority Muslim countries. But what will happen for Arab Christian Americans? What about Arab Muslim Americans whose countries were not included in the ban? What about those whose compatriots were banned? Most probably, they will intensify their assimilation, distance themselves from their culture heritage, ethnic differences and/or heighten their invisibility. Because the American government and the president himself are still normalizing Islamophobia which consequentially increases discrimination, stigmatization and violence against the Arab Americans. Besides, the Arab Americans will attempt either to assimilate completely or indulge in hyper-invisibility in order to eschew the above mentioned challenges.

\section{Reasons for Such Inflation}

Arab Americans have been assimilating willingly especially those who have similar religious traditions. But not all Arabs are Christians, so there are others, who experience forceful assimilation in order to escape stigmatization, evade violence and/or get job easily. Silencing their ethnic differences became and exigent for survival. Their assimilation was intensified in order to escape the rising of anti-immigrants sentiment and enjoy the privileges of whiteness of the white American Middle class. Thereby they decided to Anglicize their names, change their foreign appearance, ignored their cultural heritage and language in order to get a job, run their business, evade stigmatization and achieve economic 
improvement in the American society (Jamal and Naber, 2008:71). Besides, they ignored teaching the old culture and language to their children as they desire to be fully Americans (Naff, 1994:5).

In the 1930s Arab immigrants started to be projected as 'minortya' and parasites because they do not engage in productive professions like industry. They simply work in trade and peddling. "They were dubbed as drain on the American economy as they send some of their incomes to their families at home (Suleiman, 1999: 6). The rise of anti-immigrants sentiments after the economic recession in the 1930s also contributed in the accretion of the assimilation process. Besides, the socio-political and economic instability in their homeland urged them to live in the United States permanently. Suleiman (1999) further adds "after the World War II the Arab communities assimilated fully and lost their ethnic identity" (321).

Since the last decades of $20^{\text {th }}$ century and especially after 9/11 attacks the situation of Arab Americans exacerbated because of many challenging issues such as verbal harassment, victimization, hatred, marginalization, dehumanization ...etc. in the American society. These and other pressing issues forced them either to assimilate or adhere to the Arab culture and ethnic identity. Many of them decided to stick to their cultural identity whilst some others dissociated their ethnic identity and shed all the ethnic loyalties in order to evade all the disturbances.

\section{Conclusion}

Assimilation is natural phenomenon that occurs when individuals of different cultural backgrounds come into first hand contact with each other and ends up in finding themselves as part of larger national family. In the United States, Arab Americans are becoming part and parcel of the American society with almost 3.5 million. United States is known as the country of immigrants used to legislate constantly various migration 
policies in order to limit the migration flow or achieve other designed goals. Assimilation process of Arab Americans heightened remarkably because their policies isolate them from the Arab world or target them for their race. So they face some challenges in the American society and as a consequence increase their assimilation like discrimination, victimization, prejudice, stigmatization and hatred. Thereby the inflation of their assimilation co-occurs with tangible decrease of their cultural heritage. Therein, not all the Arab Americans assimilate but some of them became indistinguishable in the American society.

\section{References}

Anan Ameri, H. A. 2012. Daily Life of Arab Americans in the 21st Century. Santa Barbara California: Green Wood.

Goitein, E. 2017, Jan 31). Trump's Muslim Ban is not at all about Terrorism. Retrieved September 24, 2017, from Fortune: http://fortune. com/2017/01/31/donald-trump-muslim-ban-immigrationterrorism-discrimination/.

Kayyali, R. 2006. Arab Americans. Grean Publishing group.

Kelly, E. (2015, Jun 2). Senate Approve USA Freedom Act" . Retrieved September 24, 2017, from USA Today: https://www.usatoday. com/story/news/politics/2015/06/02/patriot-act-usa-freedomact-senate-vote/28345747/

Maccarthy, A. C. (2017, Jan 30). Is It a Muslim Ban. Retrieved September 24, 2017, from National Review: http://www.nationalreview.com/ article/444402/trumps-muslim-ban-goal-ban-sharia-supremacistsnot-all-muslims

Naber, A. J. 2008. Race and Arab Americans before and After 9/11 From Invisble citizens into visible subjects. Syracuse University Press.

Naff, A. 1994. Becoming American the Early Arab American Experience. SIUP Press.

Nasser-McMillan, S. C. 2013. Bispsychological prespectgives on Arab 
INJECT: Interdisciplinary Journal of Communication, Vol.2, No.2, Des. 2017: h. 235-246

Americans: Culture, development and Health. Springer Science and Bussiness.

Siddham, A. Y. (2017, Jan 31). Is this a Muslim Ban? Trump's Excutive Order Explained. Retrieved September 24, 2017, from The Guradian: https://www.theguardian.com/us-news/2017/jan/28/trumpimmigration-ban-syria-muslims-reaction-lawsuits

Suleiman, M. 1999. Arabs in America Building New Future. Temple University Press. 